\title{
The Methodology of Contemporary Gender Interpretation: A Study of Qirō'ah Mubādalah
}

\author{
Taufan Anggoro \\ Universitas Islam Negeri Sunan Kalijaga, \\ Yogyakarta-Indonesia
}

Corresponding Author: Taufan Anggoro, email: anggoro426@gmail.com, Jl. Marsda Adisucipto, Sleman, Daerah Istimewa

Yogyakarta 55281

\begin{abstract}
The various interpretive products that have been offered by previous feminist figures are not followed by an interpretation methodology for gender equality topics. In response to this, qirā'ah mubādalah, an interpretation methodology of 'made in Indonesia'products which are specifically related to gender and women's issues emerged. To explore more deeply, this study focuses on two things, namely how the interpretation methodology is adopted in the mubädalah and how the position of the qirā'ah mubädalah is among the ideas or thoughts of previous feminist figures. Through the descriptive-analytical method, this study seeks to decipher the mubädalah in terms of the methodology of interpretation. The hermeneutical analysis is used to study the extent to which operational forms of hermeneutics appear in the mubādalah. The result first, methodologically the mubādalah shows the existence of operational forms of hermeneutics, with more emphasis on efforts to explore context and contextualization. Second, compared to previous feminist thinkers, the methodology of interpreting the qirā'ah mubādalah is more soft, systematic and applicable in its application. Besides, qirā'ah mubādalah is also classified as a progressive interpretation, which is essentially based on the concept of monotheism and the reciprocal method.
\end{abstract}

Keywords: gender; interpretation; methodology; qirä'ah mubādalah

Abstrak: Berbagai produk penafsiran yang telah ditawarkan oleh tokoh feminis sebelumnya tidak diikuti oleh metodologi penafsiran untuk topik kesetaraan gender. Menanggapi hal ini, muncullah qirā'ah mubādalah, sebagai metodologi penafsiran produk Indonesia yang secara khusus terkait dengan gender dan masalah perempuan. Untuk mengeksplorasi lebih dalam, penelitian ini berfokus pada dua hal, yaitu bagaimana metodologi penafsiran diadopsi dalam mubādalah dan bagaimana posisi qirā'ah mubādalah di antara gagasan atau pemikiran tokoh feminis sebelumnya. Melalui metode deskriptifanalitis, penelitian ini berupaya menguraikan mubādalah dari metodologi penafsiran. Analisis hermeneutis digunakan untuk mempelajari sejauh mana bentuk operasional hermeneutika muncul dalam mubādalah. Hasilnya adalah pertama, secara metodologis mubādalah menunjukkan keberadaan bentuk operasional hermeneutika, dengan lebih menekankan pada upaya untuk mengeksplorasi konteks dan kontekstualisasi. Kedua, dibandingkan dengan para pemikir feminis sebelumnya, metodologi penafsiran qirā'ah mubādalah lebih lunak, 
sistematis dan dapat diterapkan. Selain itu, qirā'ah mubādalah juga diklasifikasikan sebagai penafsiran progresif, yang didasarkan pada konsep monoteisme dan metode timbal balik.

Kata Kunci: gender; metodologi; penafsiran; qiraāah mubādalah

\section{A. Introduction}

Talking about the problem of interpretation of the Qur'an, it is tightly related to the method and style used. Especially if it is associated with the present discourse on interpretation, the discussion will be more extensive. The situation is inseparable from the variety and complexity of various interpretations of the Qur'an that arise at present.

The diversity includes the topics raised and also the interpretation methodology used. If related to the topic, quite a several topics or issues have been discussed in the form of thematic interpretations. While those related to methodological bids are still not as intense as the emergence of thematic interpretative works.

One of the products of contemporary interpretation thought which are manifested in the form of interpretation methodology is qirā'ah mubādalah. ${ }^{1}$ Qirā'ah mubādalah does not only offer an interpretation of the Qur'an related to gender issues ${ }^{2}$ and women only but also offers a methodological interpretation. If you see the stretching of the development of further interpretation, the emergence of the idea of qirā'ah mubādalah is quite interesting.

In the realm of interpretation of the Qur'an today, interpretations that are related to gender and women's issues are more dominant as the product of

\footnotetext{
${ }^{1}$ Qirā'ah means "recitation". "Reading" here can be understood more specifically as "interpretation". The idea of mubādalah was born from the struggle of a figure named Faqihuddin Abdul Kodir, through institutions and various women's empowerment activities. As from Forum Kajian Kitab Kuning (FK3), Rahima, Fahmina, Alimat, and KUPI. Besides that, the idea of mubādalah is also a continuation of the Faqihuddin dissertation that studies the work of Abu Syuqqah. See: Faqihuddin Abdul Kodir, Qirā'ah Mubādalah: Tafsir Progresif untuk Keadilan Gender dalam Islam (Yogyakarta: IRCiSoD, 2019), 19.

${ }^{2}$ Gender is used to identify differences between men and women in terms of socio-culture. While sex is used to identify differences between men and women according to their biological anatomy. See more: H. Hanafi, "Teologi Penciptaan Perempuan: Rekonstruksi Penafsiran menuju Kesetaraan Gender," Buana Gender: Jurnal Studi Gender dan Anak 1, no. 2 (2016): 153, https:// doi.org/10.22515/bg.v1i2.408.
} 
interpretation. Not many people have tried to formulate a comprehensive and independent interpretation methodology (specifically for gender issues). That is the needed step today, at the time of the outbreak of equality between men and women.

The emergence of the idea of mubādalah has become a new hope amid interpretations that have the content of "gender equality" today that has not effectively addressed the problem of gender equality. According to Barbara Freyer Stowasser, there needs to be a work that offers methodologically how to make a proper interpretation of religious texts. ${ }^{3}$ Qirā'ah mubādalah offers a formulation of its interpretation methodology through a reciprocal interpretation which is the 'spearhead'.

It is an idea with the use of relatively new terms amid the rise and develops the feminist movement. The idea which shows how important it is to further study the qirā'ah mubādalah. The argument ultimately raises two important questions: What is the interpretation methodology used in the qirā'ah mubādalah? and how is the position of qirä'ah mubādalah in the treasures of gender and women's issues, when compared with previous feminist figures?

To answer those questions, this study uses a descriptive-analytical method and hermeneutic theoretical framework. Hermeneutics referred to here are the three aspects in the hermeneutic component, namely text, context, and contextualization. These three aspects operate synergically in understanding, interpreting, and reproducing meaning. ${ }^{4}$

This study of qirā'ah mubādalah is undertaken by describing definitions to detailed interpretation methodologies. Exposure also includes the principles used by the mubädalah in interpreting the Qur'an. The last part is a discussion which is an analysis of the methodology of qirā'ah mubādalah in terms of aspects of the text, context, and contextualization.

\footnotetext{
${ }^{3}$ The works needed are first, always be careful of the history of the Prophet's traditions accompanied by new readings. Second, it connects Muhammad as a human being and Muhammad as a Prophet in doctrinal and psychological terms. Third, understand the full history of women on the side of the Prophet who has been impressed with a full bias. See: Barbara Freyer Stowasser, Reinterpretasi Gender: Wanita dalam al-Qur'an, Hadis, dan Tafsir, ed. Mochtar Zoerni (Bandung: Pustaka Hidayah, 2001), 311-12.

${ }^{4}$ Fahruddin Faiz, Hermeneutika al-Qur'an: Tema-Tema Kontroversial (Yogyakarta: eLSAQ Press, 2011), 132.
} 
The analysis is in the form of exploration of interpretation conducted by Faqihuddin Abdul Kodir in his qirā'ah mubādalah. The hermeneutical analysis effort is expected to be able to see the extent of the comprehension of the qirā'ah mubādalah in interpreting the verses of the Koran that talk about gender. Consequently, the methodology for interpreting qirā'ah mubādalah is analyzed through the aspects of the text, context, and contextualization.

Then the next part is observing the position of the interpretation methodology qirā'ah mubädalah in the arena of gender and women's issues. This is to see the uniqueness of the methodology in responding to gender issues, especially in terms of the interpretation of the Qur'an. It is important to do so that it can be one of the triggers for a massive study of the qirā'ah mubādalah.

So far, not many works have examined the methodology of qiräah mubādalah. Within the framework of gender and women's issues, to date works have been more dominant in the study of feminist figures and their reinterpretation of religious texts. Qirā'ah mubädalah itself appeared officially only within the last one year. It can be said that this study also started the study of the qirō'ah mubädalah.

As an idea, made in Indonesia interpretation methodology is important to appear in order not to be assumed that the interpretations that have arisen are more directed towards "Arab centrists". In general, the hope is of course to be able to enrich the treasures of the interpretation of the Quran today, especially those relating to gender and women's issues.

\section{B. Regarding of Qirā'ah Mubādalah}

The word of mubādalah (مبادلة) has the meaning of replacing, changing, and exchanging. Faqihuddin Abdul Kodir (prominent figure of qirā'ah mubādalah $)^{5}$ interprets the word mubādalah as a perspective and understanding in a particular relationship between two parties, which contains the value and spirit of partnership, cooperation, distraction, reciprocity, and reciprocal principles. ${ }^{6}$

${ }^{5}$ Faqihuddin Abdul Kodir became interested in the issue of women and Islam while he was in Syria, when reading feminist debates published in the Journal of 'Ulum al-Qur'an. Furthermore, Faqihuddin finally felt called intellectually. See more: Neng Dara Affiah, Potret Perempuan Muslim Progresif Indonesia (Jakarta: Yayasan Pustaka Obor Indonesia, 2017), 253.

${ }^{6}$ This relationship is related to human relations in general, such as the State and the people, employers and workers, parents and children, teacher-students, boys and girls and others. See: Kodir, Qirāa’h Mubādalah: Tafsir Progresifuntuk Keadilan Gender dalam Islam. 
If it is concluded specifically, the qirā'ah mubādalah is a reading activity of religious texts which discuss gender equally relating to men and women through reciprocal spirit. The emergence of this mubādalah idea is motivated by two factors. First, social factors, which is the number of mainstream religious interpretations that are more often voiced by the perspective of men. ${ }^{7}$ Second, the language factor. Almost all wordings of the Qur'anic verses use male forms (mudhakkar). Yet according to some classical scholars, the use of the male form is also directed to women. ${ }^{8}$

Qirā'ah mubādalah always emphasizes the importance of understanding texts and reality. With the premise that men and women are equal subjects. The basis of their relations is cooperation, ignorance, and help. Qirā'ah mubādalah seeks to overcome the literal limitations of texts which often seem only for women, or men only. Though the message is general and includes both. ${ }^{9}$

Thus, the idea of mubādalah encourages cooperation between men and women that are participatory, fair, and mutually beneficial without discrimination. ${ }^{10}$ In general, the spirit carried by qirā'ah mubādalah starts with universal messages of humanity and justice, which is then associated with the primary Islamic texts (al-Qur'an and Hadith) used to reconstruct the understanding of the text as a whole.

\section{Basic Principles of Qirō'ah Mubādalah}

\section{Exploring the Treasury of Islamic Classic}

From the foundation and theological sources, the idea of the emergence of qirā'ah mubādalah does not come from blank space but rests on the postulates of text (al-Qur'an and Hadith) mentioned textually and conceptually. ${ }^{11}$ Specifically, the idea of mubādalah was born from a long process of maudū'ì interpretation of texts (thematic).

\footnotetext{
${ }^{7}$ While women seem to be merely complementary in this world, as in the example of the case "Interpretation of angels for godly men". Women are only used as objects of discussion, so women are often absent on the stage of religious interpretation. See: Kodir.

${ }^{8}$ This understanding approach is known as the taghlib rule, which is the inclusion of women into male editors. See: Kodir.

${ }^{9}$ Kodir.

${ }^{10}$ Kodir.

${ }^{11}$ The verses which form the basis for the emergence of the mubādalah idea are QS. al-Hujurāt [49]: 13; QS. al-Mā'idah [5]: 2; QS. al-Nisā' [4]:1 \& 19; QS. al-Anfāl:72; QS. al-Taubah [9]: 71; QS. Āli 'Imrān [3]: 195; QS. al-Rūm [30]:21 \& 31; QS. al-Baqarah [2]: 187, and others. See more: Kodir.
} 
In interpreting those texts, qirā'ah mubādalah adopted the linguistic interpretation used by classical scholars. The interpretation is done through the rules of taghlïb al-mudhakkar 'ala al-muannath..$^{12}$ Besides based on the textual representation, the idea of mubädalah is also based on one important pillar in Islam, namely tauhid (monotheism).

Faqihuddin Abdul Kodir 'translates' monotheism in the idea of mubādalah as the form of recognition of the oneness of Allah and the statement of human equality before Him. ${ }^{13}$ The meaning of tawhìd (monotheism) is in line with what was expressed by Nasaruddin Umar. ${ }^{14}$ Thus, the meaning of tawhìd (monotheism) according to Faqihuddin and Nasaruddin Umar is more specifically concerned with gender equality.

It is different from the meaning of tawhìd (monotheism) according to Siti MusdahMulia, who is more oriented to the "Spirit of Liberation". ${ }^{15}$ Mubādalah is associated with monotheism because this perspective of modesty (mubädalah) is firmly rooted in social monotheism which emphasizes equality, justice, compassion, and respect for humanity. ${ }^{16}$

The relationship between monotheism and the issue of gender equality has been stated before by Amina Wadud, one of the feminist figures. She mentioned that monotheism is a theological basis in the creation of equality between men and women. ${ }^{17}$ If examined further, the emergence of the idea of mubādalah is more or less influenced by Amina Wadud's thoughts, both through discussion and quite intense dialogue. Even so, there are differences in discourse and movement therein. In the analysis, the section will be explained further the extent of the differences between the two.

\footnotetext{
${ }^{12}$ This rule seeks to resolve texts specifically targeting one sex, but if the message is universal then it is also applied to both parties (male and female). See: Kodir.

${ }^{13}$ Kodir.

${ }^{14}$ Gender equality in the Qur'an equates the position of men and women as servants ('äbid). God and as God's representative on earth (khaliffatulläh fi al-ard). Men and women alike have the potential to achieve achievements and reach the pleasure of God in the world and the hereafter. See: Nasaruddin Umar, Argumen Kesetaraan Gender: Perspektif al-Qur'an (Jakarta: Paramadina, 2001), 306.

${ }^{15}$ Monotheism is the source of the power of enlightenment and liberation of humanity from injustice, oppression, and various other defamations as taught and practiced by Rasulullah. See more: Siti Musdah Mulia, Muslimah Reformis: Perempuan Pembaharu Keagamaan (Bandung: Mizan, 2005), 6.

${ }^{16}$ Kodir, Qirā'ah Mubādalah: Tafsir Progresif untuk Keadilan Gender dalam Islam.

${ }^{17}$ Amina Wadud Muhsin, Qur'an and Woman: Rereading He Sacred Text from a Woman's Perspective (New York: Oxford University Press, 1999).
} 


\section{Reciprocal Interpretation as the Basis of Interpretation}

The specificity of this qirā'ah mubādalah lies in the use of its reciprocal interpretation. Reciprocal, which is more easily referred to as "interdependent" (Indonesia: kesalingan) is used for two objects that experience a "gap" in terms of justice, specifically two sex objects (male and female). An example of the use of reciprocal interpretation can be seen in the explanation of Faqihuddin Abdul Kodir when discussing the topic of "Essence of the Same Creation".

The word that means "human" in the Qur'an is referred to by several terms, namely al-bashar and al-insān. According to Faqihuddin, the word albashar shows the similarity of humans (men and women) in the scope of the origin of its creation. While the word al-insān is the creation of humans from the soil. $^{18}$

Although the two words do not indicate bias, the use of pronouns is often biased. For example, the words "kum" and "hum" which are more directed to men. Through the use of the taghlïb rule, its scope becomes broader by taking part in covering women. ${ }^{19}$ The analysis of linguistic aspects is very much felt here through a review of the structure of the Arabic language.

The same steps are also used when interpreting QS. al-Nisā' [4]: 34. The difference is that Faqihuddin Abdul Kodir helped to relate it to the Arab social situation at that time when women were considered to be people who did not have a strong social capacity as leaders. ${ }^{20}$ After relating to the turmoil of the Qur'an (historical context), Faqihuddin then looked at the present context.

Faqihuddin Abdul Kodir sees that the present situation is far different from the time of the Prophet. Nowadays many women have good capacity, leadership, and service. ${ }^{21}$ So the important point, when choosing a leader is not based on gender, but the capacity and ability.

The example shows a context analysis in the qirä'ah mubädalah. An example of the interpretation of QS. al-Nisā' [4]: 34 below is provided to see clearly how the interpretation works.

\footnotetext{
${ }^{18}$ Kodir, Qirā'ah Mubādalah: Tafsir Progresif untuk Keadilan Gender dalam Islam.

${ }^{19}$ Kodir.

${ }^{20}$ Kodir.

${ }^{21}$ Kodir.
} 


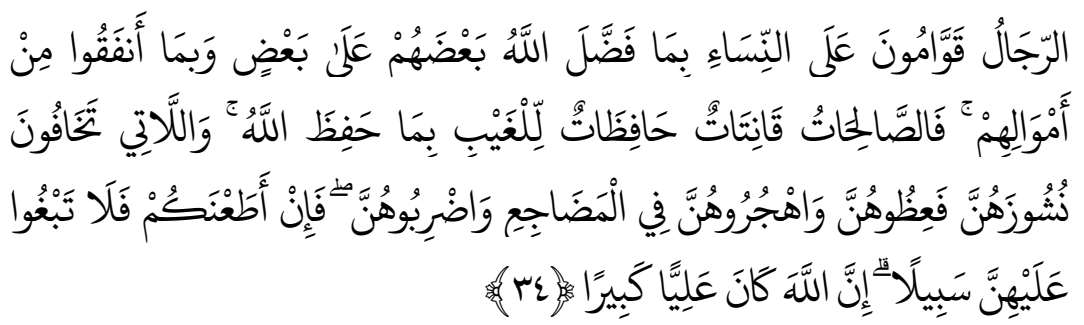

The word al-rijālu in the verse does not always mean "male". Nasaruddin Umar acknowledges the word is not merely male (gender), but someone who is associated with certain socio-cultural attributes. ${ }^{22}$ With the various meanings of the word al-rijālu, then the verse can be interpreted. ${ }^{23}$

The results of the interpretation of QS. al-Nisā' [4]: 34 is not about affirming leadership or men's responsibility towards women alone. But talking about the demands on people who have the virtue (fadl) and property (nafaqah) to share the responsibility of supporting the 'have not'.24 It can be seen that the content of gender bias in the latter interpretation has disappeared, shifted to a more universal meaning.

Reciprocal interpretation makes the taghlīb rule the main method in the qirā'ah mubādalah. Of course, the use of these rules is used after a study of the aspects of textuality is done. Consequently, the taghlïb rule is indeed the main method in reciprocal interpretation, although it is not a single method. It can be seen how at this stage the contextualization aspect seems to operate in the qirā'ah mubādalah.

\section{Principle of Justice and Partnership}

Qirā'ah mubādalah seeks to bring about justice between men and women. To realize this, there is a real implementation that wants to be addressed especially in terms of religious interpretations. First, the perspective (minzar) which humanizes women as well as men; second, how to read (qirā'ah) reference texts by placing them as whole human subjects; and third, the

\footnotetext{
${ }^{22}$ Umar, Argumen Kesetaraan Gender: Perspektifal-Qur'an.

${ }^{23}$ In the Qur'an, the word has three meanings: first, those who like to purify; second, committed people always do the zikr; third, those who will get what is promised by Allah. See: Kodir, Qirä'ah Mubādalah: Tafsir Progresif untuk Keadilan Gender dalam Islam.

${ }^{24}$ Kodir.
} 
grouping ( $\left.q \bar{a}^{\prime} i d a h\right)$ vertices of experience and law of ignorance between men and women. ${ }^{25}$

The three implementations emerge from spaces which have been encountered quite often for arbitrariness, especially between men and women. One's perspective on gender may result from reading religious texts. This reading can lead to arbitrariness and injustice when the reading is done textually.

One verse of the Qur'an whose reading often results in injustice is QS. alBaqarah [2]: 282. This verse speaks of the testimony of a man being the same as two women. In terms of the historical context, the Arab Jahiliyah period did not recognize women's testimony. ${ }^{26}$

It is precisely when the verse expresses the testimony of women "two to one" with men, the Qur'an has made a very revolutionary change. So, the problem of "two to one" testimony is contextual and functional, not principal and not in the framework of showing the superiority of men over women. ${ }^{27}$

According to Nasaruddin Umar, the revelation of al-Qur'an verses that seemed unfair to the woman had three missions: first, to gradually provide women's rights; second, a form of simplification by minimizing liabilities and increasing ability; and third, eliminating difficulties. ${ }^{28}$ In this way, the Qur'an has signaled the equality of men and women in matters of testimony.

In addition to the matters of testimony, women are also seen as more severe in terms of exercising their rights and obligations. ${ }^{29}$ This is caused by a strongly patriarchal culture and reading of partial religious texts. The idea of mubādalah requires the creation of partnership relations (cooperation) between men and women.

This partnership relationship is important, especially in the matters of marriage, household (husband and wife), child care and education, and the

\footnotetext{
${ }^{25}$ Kodir.

${ }^{26}$ The existence of women is not considered, birth is not expected, marriages can be forced, polygamy without limits, without the protection of justice, divorced and referred at any time, etc.. InKodir.

${ }^{27}$ Kodir.

${ }^{28}$ See: Umar, Argumen Kesetaraan Gender: Perspektifal-Qur'an.

${ }^{29}$ See: Khomisah Khomisah, "Rekonstruksi Sadar Gender: Mengurai Masalah Beban Ganda (Double Bulder) Wanita Karier di Indonesia," Jurnal al-Tsaqafa 14, no. 2 (2017): 399, https://doi.org/10.15575/al-tsaqafa.v14i2.2007.
} 
creation of public benefit. ${ }^{30}$ Thus qirā'ah mubādalah has far-reaching implications, namely at the level of daily practical life. Justice and partnership have always been a spirit in interpreting religious texts comprehensively.

\section{Interpretation Methodology of Qirā'ah Mubādalah}

Faqihuddin Abdul Kodir did not explain in detail the step by step of howqirā'ah mubādalah works. Faqihuddin only explained substantively, the main steps that must be taken in interpreting the Qur'an. Here is how the qirā'ah mubādalah works.

First, find and confirm the principles of Islamic teachings from texts that are universal as the foundation of meaning. ${ }^{31}$ Second, find the main ideas recorded in the texts that we will interpret. This step is taken by eliminating the subjects and objects from the text. Those steps are implemented so that the main message or idea of the text will be obtained. ${ }^{32}$

Then the third step, passing the ideas found from the text (born from the second step above) to the sexes that are not mentioned in the text. ${ }^{33}$ The last step is the application of the mubādalah method. The following is an illustration of how the mubādalah method works (Figure 1).

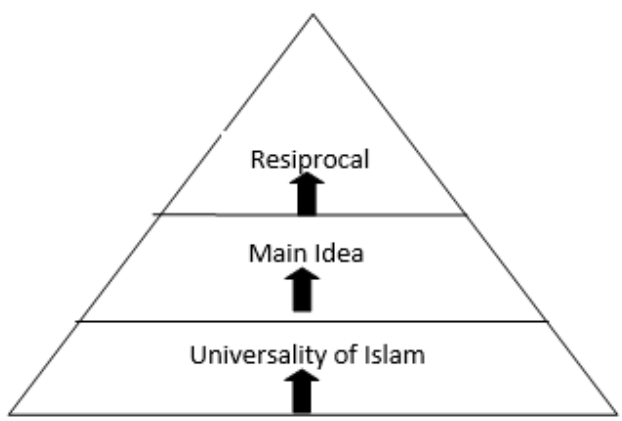

Figure 1.

The work of Mubādalah Method

\footnotetext{
${ }^{30}$ See: Kodir, Qirā’ah Mubādalah: Tafsir Progresif untuk Keadilan Gender dalam Islam.

${ }^{31}$ Kodir.

${ }^{32}$ To help get the main idea, it can be through the tools in UsulFiqh, such as qiyas, istihsan, istislah, dan dalalat al-alfaz. See: Kodir.

${ }^{33}$ Kodir.
} 
Faqihuddin Abdul Kodir then exemplifies the application of those steps by interpreting the QS. 'Ali 'Imrān [3]: 14 below:

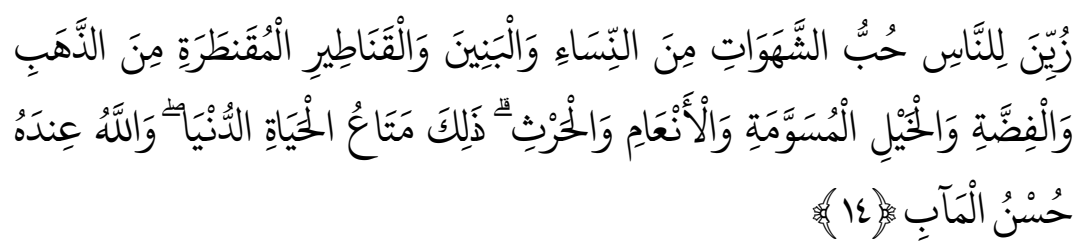

It means: "To be made beautiful in (human's) view of love for what is desired, namely: women, children, a wealth of many kinds of gold, silver, choice horses, farm animals and farm fields. That is the pleasure of life on earth, and with Allah is a good place to return (heaven)." 34

To find the principles of Islamic teachings, one must look at the basic argumentation of a text. From the studies that have been carried out, Faqihuddin sees that the universal principles of Islamic teachings view that men and women alike become the targets of the commands of faith and the ban on slipping on temptation. ${ }^{35}$

After the universal principle is discovered, the next is finding the main ideas contained in the object of the verse being studied. QS. Āli 'Imrān [3]: 14 talks about the importance of being vigilant in the jewels of the world that can derail humans (both men and women). ${ }^{36}$

The last step is to do interpretation from the main idea of the verse that has been found. The verse studied seemed to make women the sources of problems for men. Even though the verse is meaningful, whether it's male or female, each other can be one of the jewels, which can be the source of temptation. ${ }^{37}$

The application of the mubādalah method was also carried out by Faqihuddin in the topic "Parenting and Education of children". Faqihuddin assessed that the universal principle of caring for and educating children is the responsibility of husband and wife. ${ }^{38}$ Such assessment is in line with one of

\footnotetext{
${ }^{34}$ Mohammad Taufiq, "Software Qur'an in Word," n.d.

${ }^{35}$ Kodir, Qirā'ah Mubādalah: Tafsir Progresif untuk Keadilan Gender dalam Islam.

${ }^{36}$ Kodir.

${ }^{37}$ Kodir.

${ }^{38}$ This is based on the Prophet's hadith which reads, "No child is born except in a state of nature (holy and clean). It was his parents who made him Jewish, Christian, or Majusy". In addition to these
} 
Turkey's progressive thinkers, who say that Islam helps ensure the basic rights and needs of children while placing the responsibility for fulfillment on the parents. ${ }^{39}$

Faqihuddin, in discovering the principles of Islamic teachings, through almabādi' (beyond all themes) and al-qawā'id (specific themes). ${ }^{40}$ But based on his study, the principles are more dominantly found in al-mabādi'. This is of course because not all texts explain a specific case, especially if it is associated with current themes.

The three steps are taken in interpreting the Qur'an through the qiräah mubādalah show how important it is to search for the substance or idea of the verse. Those steps do not stand alone but united into an interpretation methodology. More details are described in Figure 2.

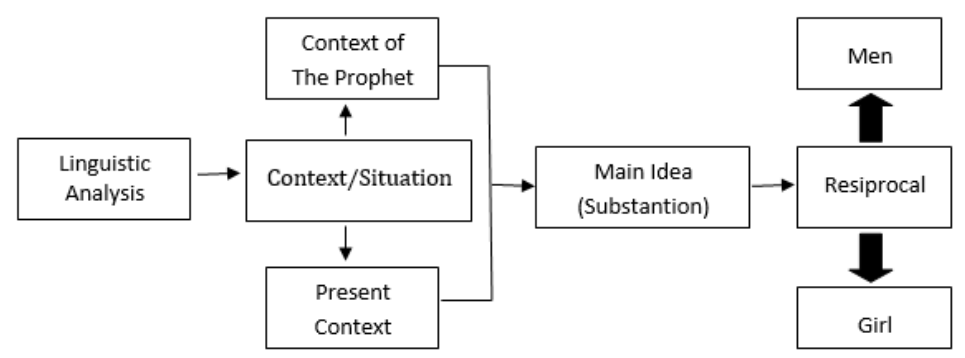

Figure 2.

The Interpretative Methodology Qirā'ah Mubādalah

The chart shows how the interpretative methodology is employed by qirā'ah mubādalah comprehensively. The picture was obtained after an intensive study of the qirā'ah mubädalah. The interpretation of the Qur'an through the method of mubādalah begins with conducting a language study, especially on the object of the intended sex. After that, a study of the context, both the historical context of the qur'anic text and the present context is done.

traditions, in the life of the Prophet Muhammad himself. The Prophet was always close to the child, taking part and taking care of him. Shows that the obligation to care for children is not only on the wife, but also on the husband. InKodir.

${ }^{39}$ Ali Husain al-Hakim, Membela Perempuan: Menakar Feminisme dengan Nalar Agama, ed. A. H. Jemala Gembala (Jakarta: al-Huda, 2005), 282.

${ }^{40}$ Kodir, Qirā’ah Mubādalah: Tafsir Progresif untuk Keadilan Gender dalam Islam. 
From the study of the context that has been carried out, we will get a universal idea of Islamic teachings and the main ideas of the text being studied. This is where the role and the position of three steps of the work of qirä'ah mubādalah, which was mentioned in the previous section. The three steps that have been described are parts of the interpretation methodology in the qirä'ah mubādalah. The qirā'ah mubādalah interpretation methodology chart is a description of the interpretation methodology used in its entirety.

The final step is a reciprocal interpretation (interdependent). This step is taken to change a text which seems biased into fairness in positioning men and women as the basis of equality and partnership. If the mașlahah is for men, then the message for the mașlahah is also addressed to women, this is the case. It should be noted, that not all text messages can be changed, some terms and conditions apply. ${ }^{41}$ This also needs attention.

\section{E. Qirō'ah Mubādalah Analysis in the Treasure of the Qur'an and Hadith Interpretation \\ Qirä'ah Mubādalah in the Perspective of Hermeneutics of the Qur'an}

Viewed from the scope of the object of study, hermeneutics has a scope in three horizons: author, text, and reader. From the procedural side, hermeneutics works in 3 regions, namely text area, context, and contextualization. ${ }^{42}$

Each of the three components of hermeneutics does not work on its own but interconnected with one another. In qirā'ah mubädalah it is seen the extent to which the three hermeneutic components are used in the interpretation. Based on the examples of interpretation of mubädalah that has been presented in the discussion section, it can be concluded that the qirā'ah mubādalah has shown the operational form of hermeneutics.

Qirä'ah mubädalah took the same path as what the previous Muslim thinkers did. ${ }^{43}$ The term used is the main idea of a verse. The path is taken by

\footnotetext{
${ }^{41}$ There are some exceptions to the use of mubādalah. Biological problems such as menstruation, pregnancy and breastfeeding cannot be ruled out (mubādalah). In addition, issues relating to aqeedah and news (information) from the text (the Qur'an and Hadith) do not apply reciprocal interpretations, but if it is related to the wisdom behind the two issues it is possible to use mubādalah. See: Kodir.

${ }^{42}$ Faiz, Hermeneutika al-Qur'an: Tema-Tema Kontroversial.

${ }^{43}$ The characters in question are: Fazlur Rahman (with his ratio legis), Nashr Hamid Abu Zayd (with term his maghza), al-Ṭalibi (with maqāṣid), and then Abdul Mustaqim with his maqāṣid.
} 
exploring historical contexts (past and present) to get the relevance of the meaning to be applied.

Besides, other operational hermeneutics such as text analysis and contextualization appear in the work of interpreting qirā'ah mubädalah. Although it is undeniable, it has not consistently accommodated the three components. Qirā'ah mubādalah is more dominant in analyzing context and contextualization.

Contextualization can be said as a hermeneutics of the Qur'an itself. ${ }^{44}$ Specifically, the contextualization step taken in the qirā'ah mubādalah lies in its reciprocal interpretation. This is evident in its interpretation of the QS. al-Nisā' [4]: 34. The verse is understood that choosing a leader is not based on gender, but capacity and ability. It says contextualization efforts because of the results of the interpretation sound 'against' the literal message of the verse.

Therefore, it is appropriate to say that the qirā'ah mubādalah is also referred to as "Reciprocal Hermeneutics". The reference is not redundant, because the qirā'ah mubādalah has become an interpretation methodology. It is an interpretation methodology that appears in contemporary times when there are many progressive interpretive ideas.

The aspect of progressiveness is also evident in the ideas of the qirä'ah mubädalah. Thus, qirā'ah mubädalah can be included in one of the schools in the typology of contemporary interpretation. The flow meant to see the progressive side of the qirā'ah mubādalah is the quasi progressive objectivist flow. ${ }^{45}$

According to Sahiron Syamsuddin, the flow seeks to find the origin of meaning (historical) as the starting point in reading the Qur'an today. Con-

\footnotetext{
${ }^{44}$ The emergence of hermeneutics itself can be used as a methodological tool in understanding religious texts in the present context. This is done to gain new and fresh understanding in the social, cultural and political context in the various regions where the text is understood. See more: Muhammad Alfatih Suryadilaga, "Kontekstualisasi Hadis dalam Kehidupan Berbangsa dan Berbudaya," Kalam 11, no. 1 (2017): 220, https://doi.org/10.24042/klm.v11i1.904.

${ }^{45}$ SahironSyamsuddin divides the typology of contemporary interpretative thought into 3 genre: First, the conservative quasi-objectivist genre. Namely the teachings of the Qur'an must be understood and interpreted today as before when the Qur'an was revealed and understood in the time of the Prophet. Second, the subjectivist flow, that is, every interpretation that is entirely left to the interpreter's subjectivity, therefore the truth is relative. And third, the progressive quasiobjectivist genre, which continues to believe in the importance of the present interpreter to explore the original meaning through the methodical means of interpretation and various other necessary devices. See: Sahiron Syamsuddin, Hermeneutika dan Pengembangan Ulumul Qur'an (Yogyakarta: Nawesea Press, 2017), 54-58.
} 
versely, the literal meaning is no longer considered as the main message of the Qur'an, it is important to know the meaning behind the literal message. ${ }^{46}$ This is consistent with what is emphasized in the idea of mubādalah to always study the historical context of the verse and the present context.

Qirā'ah mubādalah focuses its studies on verses that are considered less friendly to women, especially if it is applied today. For this reason, the idea of mubādalah emphasizes the importance of exploring the historical context so that it is known the intent and the purpose of related verse. ${ }^{47}$ By knowing the intent and purpose, it will be known the main ideas contained in the verse.

After the main idea of the verse is known the next step is to do reciprocal (interdependent) to produce a fair understanding for both men and women. Not surprisingly, the results of the interpretation of the qirā'ah mubädalah are somewhat different from what is contained in the literal message of the verse.

Therein lies the progressive side of the qirä'ah mubädalah in bearing the interpretations that fulfill a sense of justice and gender equality. The breakthrough of understanding in the form of 'against' literal meaning of the Qur'an. ${ }^{48}$ This is all inseparable from the original purpose of the mubādalah which aims at realizing the universality of Islamic teachings.

\section{Qirō'ah mubādalah in the Treasure of Gender and Women's Thought}

Many figures have focused on gender and women's issues. Among all of them are Fatimah Mernissi, Riffat Hasan, Amina Wadud Muhsin, Ali Asghar Engineer, Asma'Barlas, etc. Those from Indonesia are Masdar Farid Mas'udi, Lies Marcoes, Husein Muhammad, Mansour Fakih, Siti MusdahMulia.

Broadly speaking, the idea of mubādalah does not differ significantly from the thoughts of the figures. One concept that is considered sacred in Islam is Tauhid (monotheism). Almost all of those figures use the spirit of monotheism in campaigning for gender equality. The idea of mubādalah uses this monotheistic spirit to place men and women as equals before their Lord.

\footnotetext{
${ }^{46}$ Syamsuddin, Hermeneutika dan Pengembangan Ulumul Qur'an.

${ }^{47}$ Topics discussed through this model, for example, about the caliphate of humans on earth; women are less intellect and religion; polygamy and divorce; and others. See more: Kodir, Qirä'ah Mubādalah: Tafsir Progresif untuk Keadilan Gender dalam Islam.

${ }^{48}$ Topics interpreted through the model, for example in the topics 'iddah and ihdad; childcare and education; women's humanitarian dignity; nymphs and male fairy in heaven; and others. See more: Kodir.
} 
In the arena of thought, the step is indeed unique. Monotheism is usually often voiced by some Islamic groups who are scripturalist-revivalist through their puritan movements. ${ }^{49}$ The monotheistic model that is often voiced by this group is more theocentric. ${ }^{50}$ Monotheism is used by the group precisely to negate other parties who are different from the group. So what happens is the emergence of the 'gap' as it is getting easier to identify the difference through 'our group' and 'their group'.

This is different from the spirit of monotheism that is carried out in the idea of mubādalah, which is more anthropocentric. ${ }^{51}$ This is evidenced by Faqihuddin Abdul Kodir's efforts to make monotheistic spirit a foothold even in bearing progressive interpretations. ${ }^{52}$ In other words, the concept of monotheism undergoes 'modification', so that the resulting meaning is more 'down to earth' and based on humanity.

If feminist figures such as Fatimah Mernissi, Amina Wadud, Ali Asghar Engineer, and Rifat Hasan are more dominant in discussing a topic, then reinterpretation is carried out. ${ }^{53}$ In this case, the qirā'ah mubädalah is more than that, namely compiling a systematic interpretation methodology. The targets and topics studied are the same, they are the verses of the Qur'an which are considered less friendly to women, or in Fatima Mernissi's term is a misogynist. $^{54}$

\footnotetext{
${ }^{49}$ Haedar Nashir, Islam Syariat: Reproduksi Salafiyah Ideologis di Indonesia (Bandung: Mizan Pustaka, 2013), 455-56.

${ }^{50}$ Theocentric is a theology (kalam) whose discussion is only about the problems of the divine, mantiqiyat, and tabi'iyat. In other words, this theocentric makes "God" as a central thing (center) in every discussion. See: Hasan Hanafi, Dirasah Islämiyyah (Cairo: Maktabah al-Mișriyyah, n.d.), 394-415.

${ }^{51}$ Anthropocentric is a theology (Kalam science) in which the orientation of all its discussions is human. The aim of this theology is to exploit the realm of humanity, care for social change, ignorance, poverty and underdevelopment. M. Gufron, "Transformasi Paradigma Teologi Teosentris Menuju Antroposentris: Telaah atas Pemikiran Hasan Hanafi," Millati: Journal of Islamic Studies and Humanities 3, no. 1 (2018): 169, https://doi.org/10.18326/mltv3i1.141-171.

${ }^{52}$ Which is used to embrace all groups so that they can work together in building benefit. Kodir, Qirā'ah Mubādalah: Tafsir Progresif untuk Keadilan Gender dalam Islam.

${ }^{53}$ Discussions are conducted around the creation of humans, clothing, women and careers, and around the household. See more: Janu Arbain, Nur Azizah, and Ika Novita Sari, "Pemikiran Gender Menurut Para Ahli: Telaah atas Pemikiran Amina Wadud Muhsin, Asghar Ali Engineer, dan Mansour Fakih," Sawwa: Jurnal Studi Gender 11, no. 1 (2015): 77-90, https://doi.org/10.21580/ sa.v11i1.1447.

${ }^{54}$ Actually there is no term "Misogynist Hadith", but what is meant is the understanding of the hadith that seem "Misogynist". Ahmad Fudhaili, Perempuan di Lembaran Suci: Kritik atas Hadis-Hadis Shahih (Jakarta: Kementerian Agama Republik Indonesia, 2012), 284.
} 
The feminist movement echoed by feminist figures carries a more "suing" spirit so that it provokes protests to the point of being comprehended. ${ }^{55}$ One example is the mass actions in various countries as the forms of protest and criticism directed at Amina Wadud. ${ }^{56}$ This is different from the offer of qirä'ah mubādalah which is more soft, systematic, and applicable.

It is said to be soft because, in terms of its analysis, mubādalah rests on a fairly strong classical scientific treasure, one of which is 'Ulūm al-Qur'ān. As explained in the interpretation section of the mubādalah, 'Ulūm al-Qur'ān is used to analyze the linguistic aspects of the verses of the Qur'an. These efforts can not be separated from the figure of Faqihuddin Abdul Kodir who has a strong Islamic educational background. ${ }^{57}$

To borrow a term introduced by Nashr Hamid Abu Zayd, the reading model (qirā'ah) offered by the idea of mubādalah is productive reading (alqirā'ah al-muntijah) of the Qur'an, not repetitive reading or ideologicaltendentious reading. ${ }^{58}$ The topics discussed in the mubädalah idea are quite up to date (Indonesian context), ${ }^{59}$ not only limited to topics that have been 'routine' discussion of feminist figures.

In Indonesia itself, gender and women's issues began to emerge in the period of the 1980 s to the 1990 s. $^{60}$ Then in the 2000s increasingly massive

\footnotetext{
${ }^{55}$ See more: Dawam Mahfud, Nafatya Nazmi, and Nikmatul Maula, "Relevansi Pemikiran Feminis Muslim dengan Feminis Barat," Sawwa: Jurnal Studi Gender 11, no. 1 (2015): 108, https://doi.org/10.21580/sa.v11i1.1448. The authors of the article are less complete in describing western feminists and Muslim feminists, as well as gender-feminist issues in general. It is true that Islam regulates the rights and obligations of men and women equally. But what becomes an important issue of gender and feminists is around the interpretation or interpretation of texts. Therefore the steps taken are reinterpreting. So the issue is not the "Islam", but a partial interpretation of the Qur'an and the hadith. The authors of the article seem to have failed in distinguishing between Islam and interpretation.

${ }^{56}$ One of the actions that received the attention of many people was when Amina Wadud became the imam of Friday prayers. See more: Irsyadunnas, Hermeneutika Feminisme dalam Pemikiran Tokoh Islam Kontemporer, ed. M. Fatih Mansur (Yogyakarta: Kaukaba, 2014), 295.

${ }^{57}$ Faqihuddin Abdul Kodir was a student at the Dar at-Tauhid Arjawinangun Islamic Boarding School in Cirebon. Then study S1 at Damascus University. Then S2 in the field of fiqh at IIUM Malaysia, and graduated from the UGM ICRS program. See more: Kodir, Qirā'ah Mubädalah: Tafsir Progresif untuk Keadilan Gender dalam Islam.

${ }^{58}$ Nașr Ḥamīd Abū Zayd, Naqd al-Khițab al-Dīnī (Cairo: Sina li an-Nașr, 1994), 142-46.

${ }^{59}$ Examples of current topics raised in the qirä'ah mubädalah such as women, prophethood, and religious; public and social benefit; five pillars that support household life; regarding relations, livelihood, and sex between couples. Kodir, Qirä’ah Mubādalah: Tafsir Progresif untuk Keadilan Gender dalam Islam.

${ }^{60}$ The issues discussed at that time were about the reinterpretation of the themes of the nature and creation of men, women's leadership, inheritance of women, and entering the early 2000s,
} 
studies of religious texts were interpreted with the spirit of equality. It has grown even more by reviewing classical books, such as that of Husein Muhammad, who conducted a study of the book of 'Uqud al-Lujain. ${ }^{61}$

Eni Zulaiha saw that Indonesian feminist figures did more synthesis than what had been discussed by previous feminist figures, then formulated something new. ${ }^{62}$ Examples of the formation of these patterns are reflected in theqirā'ah mubādalah, such as the use of the concept of monotheism and the importance of studying the historicity of texts. Although indeed, in this study, qirā'ah mubādalah does not only do synthesis but also systematization. It's no longer a discourse but has become a practical methodology.

In their efforts to fight for gender and women's rights, qirä'ah mubādalah also adopted the concept of monotheism Amina Wadud. This concept is then used as the spirit in bearing the interpretations that are friendly to women. How men and women are equally positioned as 'âbid. Even so, the idea of mubādalah seems to have a stronger foothold in the treasures of the classical Islamic tradition.

It cannot be separated from the influence of the thought of Husein Muhammad who was quite dominant. This is seen in the integration of gender analysis (originating from the West) with classical scientific treasures through a hermeneutic approach. ${ }^{63}$ Interestingly, because it forms a circle of pesantren, where Husein Muhammad himself has a scientific background pesantren. The pesantren environment, which has often been associated with "patriarchal culture", is precisely now able to become a gender-just base and circle (network) of thought.

From the studies and discussions that have been presented, qirā'ah mubädalah through the reciprocal method is applicative. This is because the reciprocal method is applied through "interdependence". The point is that if in

which slightly warmed up the issue of polygamy. See more: Affiah, Potret Perempuan Muslim Progresif Indonesia. 71-79.

${ }^{61}$ Husein Muhammad, Islam Tradisional yang Terus Bergerak (Yogyakarta: IRCiSoD, 2019),

${ }^{62}$ Eni Zulaiha, "Tafsir Feminis: Sejarah, Paradigma dan Standar Validitas Tafsir Feminis," AlBayan: Jurnal Studi Ilmu al-Qur'an dan Tafsir 1, no. 1 (2016): 20, https://doi.org/10.15575/albayan.v1i1.1671.

${ }^{63}$ Husein Muhammad used a contextual-philosophical approach and included gender analysis in his interpretation. The interpretation revolves around the study of the historicity of the Qur'anic text and patterns of understanding texts that focus on the scope of the relation of the text, the context, and the author. For more information: Eni Zulaiha, "Analisa Gender dan Prinsip-Prinsip Penafsiran Husein Muhammad pada Ayat-Ayat Relasi Gender," Al-Bayan: Jurnal Studi Ilmu al-Qur'an dan Tafsir 3, no. 1 (2018): 1-11, https://doi.org/10.15575/al-bayan.v3i1.3125. 
the Qur'an the subject which is burdened with something only mentions men, then it applies to women. it means it is simpler and easier to implement.

It is in line with current phenomena, where social media has become one with everyday life. Almost all of the current discussion is voiced through social media. Qirā'ah mubādalah is very precise and quite relevant in doing counterdiscourse (especially religious) in cyberspace. Simple interpretation (reciprocal) can be used and applied to counter various Islamic discourses that always corner women.

\section{F. Conclusion}

Qirā'ah mubādalah has shown a form of operational hermeneutics. This is demonstrated by its efforts in exploring aspects of the text, context, and contextualization in its interpretation. Although not yet consistently accommodate those three components., it does more context analysis (past and present) and contextualization. The contextualization step is demonstrated through its reciprocal interpretation.

Besides, qirā'ah mubādalah is classified as a progressive interpretation. The progressive qirā'ah mubādalah is seen in its efforts to bear interpretations that fulfill a sense of justice and gender equality between men and women. Qirā'ah mubādalah has a soft, systematic, and applicable character. The topics discussed in the idea of mubādalah are quite up to date (Indonesian context), not only topics that have been 'routine' discussions of feminist figures.

Qirā'ah mubādalah adopts the concept of monotheism offered by Amina Wadud. The idea of mubādalah makes the concept a spirit to bear interpretations that are gender fair. This step is a synthesis of what has been preached by previous feminist figures. In terms of application, qirā'ah mubādalah through the method of simplicity is simpler and easier to apply in daily life. It can be said that qirä'ah mubädalah is primarily based on the concept of monotheism and the method of reciprocal.[s]

\section{References}

Affiah, Neng Dara. Potret Perempuan Muslim Progresif Indonesia. Jakarta: Yayasan Pustaka Obor Indonesia, 2017. 
Taufan Anggoro

Arbain, Janu, Nur Azizah, and Ika Novita Sari. "Pemikiran Gender menurut Para Ahli: Telaah atas Pemikiran Amina Wadud Muhsin, Asghar Ali Engineer, dan Mansour Fakih." Sawwa: Jurnal Studi Gender 11, no. 1 (2015): 75-94. https://doi.org/ 10.21580/sa.v11i1.1447.

Faiz, Fahruddin. Hermeneutika al-Qur'an: Tema-Tema Kontroversial. Yogyakarta: eLSAQ Press, 2011.

Fudhaili, Ahmad. Perempuan di Lembaran Suci: Kritik Atas Hadis-Hadis Shahih. Jakarta: Kementerian Agama Republik Indonesia, 2012.

Gufron, M. "Transformasi Paradigma Teologi Teosentris menuju Antroposentris: Telaah atas Pemikiran Hasan Hanafi." Millati: Journal of Islamic Studies and Humanities 3, no. 1 (2018): 141-71. https://doi.org/10.18326/mlt.v3i1.141171.

al-Hakim, Ali Husain. Membela Perempuan: Menakar Feminisme dengan Nalar Agama. Edited by AH Jemala Gembala. Jakarta: al-Huda, 2005.

Hanafi, H. "Teologi Penciptaan Perempuan: Rekonstruksi Penafsiran menuju Kesetaraan Gender." Buana Gender: Jurnal Studi Gender dan Anak 1, no. 2 (2016): 143-63. https://doi.org/10.22515/bg.v1i2.408.

Ḥanafi, Hasan. Dirasah Islāmiyyah. Cairo: Maktabah al-Miṣriyyah, n.d.

Irsyadunnas. Hermeneutika Feminisme dalam Pemikiran Tokoh Islam Kontemporer. Edited by M. Fatih Mansur. Yogyakarta: Kaukaba, 2014.

Khomisah, Khomisah. "Rekonstruksi Sadar Gender: Mengurai Masalah Beban Ganda (Double Bulder) Wanita Karier di Indonesia." Jurnal al-Tsaqafa 14, no. 2 (2017): 397-411. https://doi.org/10.15575/al-tsaqafa.v14i2.2007.

Kodir, Faqihuddin Abdul. Qirā’ah Mubādalah: Tafsir Progresif untuk Keadilan Gender dalam Islam. Yogyakarta: IRCiSoD, 2019.

Mahfud, Dawam, Nafatya Nazmi, and Nikmatul Maula. "Relevansi Pemikiran Feminis Muslim dengan Feminis Barat." Sawwa: Jurnal Studi Gender 11, no. 1 (2015): 95110. https://doi.org/10.21580/sa.v11i1.1448.

Muhammad, Husein. Islam Tradisional yang Terus Bergerak. Yogyakarta: IRCiSoD, 2019.

Muhsin, Amina Wadud. Qur'an and Woman: Rereading He Sacred Text from a Woman's Perspective. New York: Oxford University Press, 1999.

Mulia, Siti Musdah. Muslimah Reformis: Perempuan Pembaharu Keagamaan. Bandung: Mizan, 2005. 
Nashir, Haedar. Islam Syariat: Reproduksi Salafiyah Ideologis di Indonesia. Bandung: Mizan Pustaka, 2013.

Stowasser, Barbara Freyer. Reinterpretasi Gender: Wanita dalam al-Qur'an, Hadis, dan Tafsir. Edited by Mochtar Zoerni. Bandung: Pustaka Hidayah, 2001.

Suryadilaga, Muhammad Alfatih. "Kontekstualisasi Hadis dalam Kehidupan Berbangsa dan Berbudaya." Kalam 11, no. 1 (2017): 215. https://doi.org/ 10.24042/klm.v11i1.904.

Syamsuddin, Sahiron. Hermeneutika dan Pengembangan Ulumul Qur'an. Yogyakarta: Nawesea Press, 2017.

Taufiq, Mohammad. "Software Qur'an in Word," n.d.

Umar, Nasaruddin. Argumen Kesetaraan Gender: Perspektif al-Qur'an. Jakarta: Paramadina, 2001.

Zayd, Nașr Ḥamīd Abū. Naqd al-Khitab al-Dīnī. Cairo: Sina li an-Nașr, 1994.

Zulaiha, Eni. "Analisa Gender dan Prinsip-Prinsip Penafsiran Husein Muhammad pada Ayat-Ayat Relasi Gender." Al-Bayan: Jurnal Studi Ilmu al-Qur'an dan Tafsir 3, no. 1 (2018): 1-11. https://doi.org/10.15575/al-bayan.v3i1.3125.

___ "Tafsir Feminis: Sejarah, Paradigma dan Standar Validitas Tafsir Feminis." AlBayan: Jurnal Studi Ilmu al-Qur'an dan Tafsir 1, no. 1 (2016): 17-26. https://doi.org/10.15575/al-bayan.v1i1.1671. 
This page intentionally left blank. 